\title{
Mapping the Potential and the Development of Kendran as a Tourism Village Model in Bali
}

\author{
Ni Putu Nina Eka Lestari ${ }^{1}$, I Nyoman Rasmen Adi $^{2}$, Ni Nyoman Reni Suasih ${ }^{3}$, Alit Sumantri ${ }^{4}$ \\ $1,2,4$ Universitas Pendidikan Nasional \\ ${ }^{3}$ Fakultas Ekononi dan Bisnis, Universitas Udayana \\ Email: 1nina@undiknas.ac.id, ${ }^{2}$ rasmenadi@undiknas.ac.id, ${ }^{3}$ renisuasih@unud.ac.id, \\ ªlitsumantri@undiknas.ac.id
}

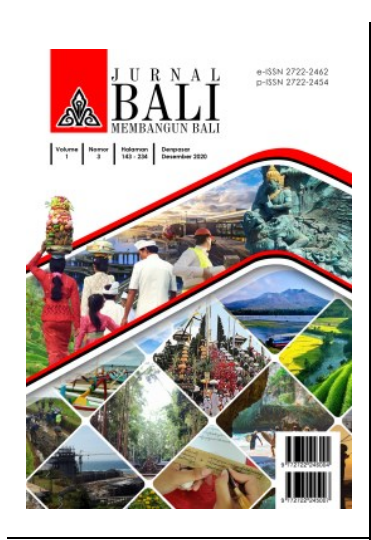

Sejarah Artikel

Submitted on

17 Juli 2020

Revised on

20 Juli 2020

Accepted on 12 Agustus 2020

\section{Abstract}

Purpose: (1) Compile a baseline study of the potential of tourist objects and attractions as well as the readiness of community participation in the Community Based Tourism development model and forms of collaboration with relevant stakeholders; (2) Strengthening institutional and community empowerment in developing Kendran Tourism Village, as a community-based tourism village; and (3) Establishment of cooperation models and policies that can be developed by local governments and related stakeholders.

Research methods: the method of documentation, questionnaires, interviews, and FGD. The collected data was then analyzed using existing condition analysis techniques, ADO-ODTWA assessment, participatory rural analysis (PRA), SWOT analysis, MACTOR analysis, and MULTIPOL analysis.

Findings: Kendran Village as a tourist village, as well as its readiness for development were quite potential. The main policies that need to be prioritized include increasing the capacity of rural communities, strengthening village tourism institutions, packaging attractions / attractions for creating branding, and expanding and maintaining markets. Implications: the development of a single destination tourist village is the creation of branding, while the policy to increase the capacity of rural communities has the highest value in the multiple destination tourist village scenario. Tourism development policy in the Province of Bali refers to the concept of sustainable and quality tourism, through various multi-sector policies.

Keywords: tourism village, CBT, potential mapping, institutional, policy.

\section{Abstrak}

Tujuan: (1) Menyusun baseline studi terhadap potensi obyek dan daya tarik wisata serta kesiapan partisipasi masyarakat dalam model pengembangan Community Based Tourism serta bentuk kerjasama dengan stakeholder terkait.; (2) Melakukan penguatan kelembagaan dan pemberdayaan masyarakat dalam pengembangan Desa Wisata Kendran, sebagai desa wisata berbasis masyarakat; dan (3) Pembentukan model kerjasama dan kebijakan yang dapat dibangun oleh pemerintah daerah dan stakeholder terkait.

Metode Penelitian: metode dokumentasi, kuesioner, wawancara, dan FGD. Data yang terkumpul selanjutnya dianalisis dengan teknik analisis kondisi existing, penilaian ADOODTWA, participatory rural analysis (PRA), analisis SWOT, analisis MACTOR, dan analisis MULTIPOL.

Temuan: Desa Kendran sebagai desa wisata, serta kesiapan pengembangannya adalah cukup potensial. Kebijakan utama yang perlu diprioritaskan antara lain peningkatan kapasitas masyarakat desa, penguatan kelembagaan desa wisata, pengemasan atraksi/daya tarik wisata penciptaan branding, serta perluasan dan pemeliharaan pasar.

Implikasi: pengembangan desa wisata single destination adalah penciptaan branding, sementara kebijakan peningkatan kapasitas masyarakat desa memiliki nilai tertinggi pada skenario desa wisata multiple destination. Kebijakan pengembangan pariwisata di Provinsi Bali mengacu pada konsep sustainable and quality tourism, melalui berbagai kebijakan multisektor.

Kata kunci: desa wisata, CBT, pemetaan potensi, kelembagaan, kebijakan. 


\section{INTRODUCTION}

Tourism is one of the sectors that makes an important contribution to national and regional economic growth. the contribution of the tourism sector to Gross Domestic Product (GDP) has reached 3.8 percent and if you take into account the multiplier effect, the contribution of tourism to GDP reaches around 9 percent. As stated in the World Economic Forum, Indonesia's tourism competitiveness increased to 70 out of 140 countries from the previous ranking

74. Meanwhile in the ASEAN region, Indonesia's tourism competitiveness is in the fourth rank. The Province of Bali is one of the areas that is the highest tourist destination in Indonesia. The level of foreign tourist visits in Bali Province contributed 14.48 percent, followed by Batam Island with a contribution of 10.9 percent (http://www.bali.bisnis.com).

In line with the increasingly dynamic dynamics of the tourism sector, one form of tourism development is a tourist village aimed at sustainable rural development. A tourism village is a form of integration between attractions, accommodation and supporting facilities that are presented in a structure of community life that integrates with the prevailing procedures and traditions (Nuryanti, 1993). The actors and experts in the tourism sector agree to emphasize that tourism patterns should minimize negative impacts on the local environment and culture and be able to increase economic income for local communities and conservation value (Ministry of Culture and Tourism and WWF-Indonesia, 2009).

The concept of community-based tourism (Community Based Tourism) emphasizes the active role of the community in managing tourism activities in areas that are traditionally owned. Choy (1997) in Fandeli and Mukhlison (2000) explains that there are five main aspects of tourism development, namely: (1) the existence of natural and cultural authenticity; (2) community presence and support; (3) education and experience; (4) sustainability; and (5) tourism management management capabilities.

One of the areas in Bali Province which is a major tourist destination and is known as "the earth of arts" is Gianyar Regency. Tourism development in Gianyar Regency tends to emphasize the rural atmosphere and the sociocultural authenticity of the local community. One of the innovation breakthroughs that need to be done is through the development of a Tourism 
Village. One of the villages included in the tourism village development program in Gianyar Regency, Bali Province, is Kendran Village which is located in Tegallalang District, Gianyar Regency. The population of Kendran Village until 2014 (BPS projection) is 8,509, consisting of 4,234 men and 4,275 women with a sex ratio of 99.04 (https://id.wikipedia.org/wiki/Kendran,Tegallalang, Gianyar).

Research conducted in Kendran Village, Gianyar Regency will be used as a form of tourism development innovation that is able to accommodate the natural, cultural and empowerment potential of local communities, namely by developing a community-based tourism village model. According to Kartika, et al. (2017), in general there are 3 (three) things that tourists value when going on a tour of a tourist attraction, namely something to see (something tourists can see), something to do (something tourists can do), and something to buy (something tourists can buy). The internal potential of tourism in Kendran Village is studied from the aspects of destination, industry, marketing and institutions as a basis for formulating its development strategy. Tourism village development is also supported by tourism institutions through the formation of a Tourism Awareness Group (Kelompok Sadar Wisata/Pokdarwis).

The objectives of this research are: (1) To compile a baseline study on the potential of tourism objects and attractions as well as the readiness of community participation in the Community Based Tourism development model and the form of cooperation with related stakeholders; (2) Strengthening institutions and community empowerment in the development of Kendran Tourism Village, as a community-based tourism village; (3) Formation of cooperation models and policies that can be developed by local governments and related stakeholders; and (4) Hierarchical mapping of policy frameworks (scenarios, policies, and actions) for developing tourist villages.

\section{LITERATURE STUDY AND RESEARCH METHODS}

Tourism activities are activities that bring people together with a situation outside their environment and can cause a sense of awe, feel comfortable and can even pose a challenge to them (Taroepratjeka, 1998). The integration of tourist objects and attractions with the development of tourism services and facilities will serve to increase tourist attraction as well as the development of 
new tourist objects and attractions. These efforts need to be supported by adequate infrastructure (Taroepratjeka, 1998).

The role of the community in the implementation of tourism is very large and needs to be balanced with the roles of the government and the private sector. However, in reality, the role of the community is still very small when compared to the other two stakeholders. The cause is the absence or weak access they have to existing tourism resources and their low involvement in the decision-making process (Sunaryo, 2013).

The World Trade Organization (WTO) defines sustainable tourism development as development that meets the needs of today's tourists, while protecting and encouraging opportunities for the future. Sustainable tourism products are integrated in harmony with the local environment, society and culture, so as to provide permanent benefits and not become victims of the exploitation of tourism development. Therefore, sustainable tourism development policies are more directed at the use of natural resources and the use of human resources in the long term (Sharpley, 2000).

The basic principles of sustainable tourism development according to Sharpley (2000) refer to the basic principles of sustainable development. Sustainable tourism development is characterized by four conditions, namely: 1) community members must participate in the tourism planning and development process; 2) education for the community, industry players and visitors or tourists; 3) maintaining environmental quality; and 4) investment in the availability of tourism infrastructure.

A tourist village is a rural area that has the potential for uniqueness and distinctive tourist attraction, both from the socio-economic life, socio-culture, unique customs, village spatial structures which are all managed attractively and naturally with the development of tourism supporting facilities. A tourism village is a form of integration between attractions, accommodation and supporting facilities that are presented in a structure of community life that integrates with the prevailing procedures and traditions (Nuryanti, 1993).

The concept of developing a tourism village contains several principles, namely (1) Not against the customs or culture of the community; (2) Physical development to improve the quality of the village environment; (3) Paying attention to elements of locality and authenticity; (4) Empowering tourism village 
communities in every aspect of tourism; and (5) Paying attention to carrying capacity and having an environmental perspective.

The involvement of the community in the development and management of tourism is an important factor, because it is the community who understands and controls their territory (Elfianita, 2011). Since local people understand the potential of their respective regions, especially their tourism potential, in order to take advantage of tourism opportunities it is deemed relevant for communities who have tourism potential to develop community-based tourism. Community Based Tourism (CBT) is community-based tourism, where the community has the authority and determinants in various aspects of tourism development itself (Sugiarti and Argyo, 2009).

There are four goals that are desired with the application of the concept of community-based tourism, namely: (1) Community-based tourism must contribute to increasing and or improving the conservation of natural or cultural resources, including biodiversity; (2) Community-based tourism must contribute to local economic development so as to increase income and benefits for the community; (3) Community-based tourism must involve the participation of local communities; and (4) Community-based tourism has a responsibility to tourists to provide products that care for the natural, social and cultural environment. Community-based tourism must pay attention to the involvement of local communities which is an absolute requirement for achieving sustainable tourism development (Pitana and Diarta, 2009).

Suansri (2003) in Nurhidayati (2004) mentions several principles of Community Based Tourism that must be carried out, namely: (1) Recognizing, supporting, and promoting community ownership in tourism; (2) Involving community members from every stage of tourism development in various aspects; (3) Promote pride in the community concerned; (4) Improve the quality of life; (5) Ensuring environmental sustainability; (6) Protecting the characteristics (uniqueness) and culture of the local community; (7) Developing cross-cultural learning; (8) Respect for cultural differences and human dignity; (9) Distribute profits and benefits proportionally to community members; (10) Contribute a certain percentage of the income earned for community development; and (11) Accentuate the authenticity of the community's relationship with the environment. 
This research is a type of Action Research research, with the research location in Kendran Village, Tegallalang District, Gianyar Regency. The type of data that will be used is perceptual data and existing data. The data collection techniques used documentation methods, questionnaires, interviews, and FGD. The collected data were then analyzed using the existing condition analysis technique, ADO-ODTWA assessment, participatory rural analysis (PRA), SWOT analysis, MACTOR analysis, and MULTIPOL analysis.

\section{RESULTS AND DISCUSSION}

\section{Existing Condition of Kendran Village}

Kendran Village consists of 10 (ten) banjars and 3 (three) traditional villages. The ten banjars are: Banjar Kepitu, Banjar Kenderan, Banjar Gunaksa, Banjar Pinjul, Banjar Dukuh, Banjar Triwangsa, Banjar Tengah, Banjar Tangkas, Banjar Pande, and Banjar Dlodblumbang. While the traditional villages in the Kendran Village area are Adar Dlodblumbang Village (which has a pengempon banjar, namely Banjar Dlodblumbang), Manuaba Traditional Village (which has a pengempon banjar, namely Banjar Pande, Banjar Tangkas, Banjar Tengah, Banjar Triwangsa, Banjar Gunaksa, Banjar. Pinjul, and Banjar Dukuh), as well as Desa Adar Kendran (which has a pengempon banjar, namely Banjar Kendran and Banjar Kepitu).

Kendran Village has the potential for natural tourism attractions that can be developed in potentials, namely: (1) Fauna in the form of monkeys that live freely in the area of Pura Dalem, Kendran Village and live freely on the edge of Tukad Petanu (Petanu River); (2) Masalembo waterfall; and (3) Rice Terrace or rice fields called terraces. Kendran Village has the potential for cultural tourism attractions that can be developed in potentials, namely Puri Kendran, traditional irrigation systems in Kendran Village or Subak Kendran, Petirtaan Telaga Waja, Pesiraman Dedari at Taman Sari Temple, Pancoran Pengelukatan, Pesiraman Geria Manuaba, Sorkopagus and Nekara in Pura Desa / Puseh Desa Kendran, ancient statues in the area of Pura Puseh in Kendran Village, Pura Geria Sakti Manuaba, Mepeed ceremony at Pura Geria Sakti Manuaba, Barong Ngelelawang culture, Mekiist activities carried out before Piodalan Pura Sakti Manuaba, dance arts such as masks and joged in Banjar Triwangsa, carvings and handicrafts sold to the village of Ubud. 
Kendran Village is able to collaborate natural and artificial attractions to become elements of the potential artificial tourist attractions that can be developed, as follows: (1) There are trekking routes that are developed to enjoy the natural atmosphere and culture of the people of Kendran Village; (2) The existence of Cycling Tour lanes to enjoy natural beauty through main roads and footpaths in Kendran Village; (3) Learning Program (lesson program) such as art cultural lesson, farm lesson, cooking lesson and mejejahitan lesson; (4) Programs that boost skills and dexterity, such as traditional game programs, village tour programs and outing programs; (5) Establishing a yoga center or yoga program such as a yoga and meditation program; (6) Puppet show every Purnama and Tilem; and (7) Temple Tour.

Institutionally, the Kendran Village area as a tourism village has been managed by the Tourism Awareness Group (Pokdarwis). The Tourism Awareness Group or abbreviated PokDarWis is a self-help and self-help group that grows from, by and for the community and aims to increase regional tourism development and the success of national tourism development.

\section{Assessment of Tourism Objects and Attractions in Kendran Village}

Assessment of the object and attractiveness of Kendran Village includes several elements of assessment, namely aspects of tourist attraction, accessibility, socio-economic environmental conditions, accommodation and supporting infrastructure.

Table 1.The results of the assessment of the Kendran village tourism attraction [Source: Primary Data, 2019, processed]

\begin{tabular}{rlccc}
\hline No. & Unsur & Nilai & Skor & Keterangan \\
\hline 1. & Aspek Daya Tarik Wisata & 141,71 & 850,25 & Potensial \\
\hline 2. & Aksesibilitas & 110 & 550 & Cukup Potensial \\
\hline 3. & Kondisi Lingkungan Sosial Ekonomi & 90 & 450 & Cukup Potensial \\
4. & Akomodasi & 50 & 150 & Tidak Potensial \\
\hline 5. & Sarana dan Prasarana Penunjang & 40 & 120,80 & Tidak Potensial \\
\multicolumn{2}{c}{ Rata-rata } & & 424,21 & Cukup Potensial \\
\hline
\end{tabular}

Keterangan : 122 - 394 : Tidak Potensial; 395 - 667 : Cukup Potensial; 668 - 940 : Potensial

Based on the classification in the development of tourism objects, Kendran Tourism Village has an assessment of the potential attractiveness of objects to be developed into tourist destinations. The tourist attraction of 
Kendran Village has the potential to be developed not only for the potential for natural beauty, but also for traditional arts and religious ceremonies that are inherent as local culture. Congestion and noise need to be anticipated for the convenience of tourist attractions because road access is relatively small, and the width of the road is still small, as well as the limited public parking space at tourist sites. The potential value of the accessibility aspect is due to a number of indicators that are still low, namely the road condition which is considered not good and the width of the road is still limited. The aspect of socio-economic conditions also shows a fairly potential assessment. The accommodation aspect still has a very low rating. This is due to the limited availability of tourist facilities such as homestays and restaurants. The aspect of the availability of tourism facilities and infrastructure also shows a low assessment. This is due to the lack of tourism support facilities, such as restaurants, shopping centers, banks, souvenir shops and public toilets as well as public transportation facilities.

\section{Readiness Assessment in Tourism Village Development}

Assessment of the readiness of developing a community-based tourism village (Community Based Tourism) is divided into four aspects of the assessment, namely socio-economic aspects, socio-cultural aspects, environmental aspects and management aspects.

Table 2 Results of the Assessment of the Readiness of the Development of Kendran Tourism Village

[Source: Primary Data, 2019, processed]

\begin{tabular}{rlrrc}
\hline No. & Prinsip & Nilai & Skor & Keterangan \\
1. & Aspek Sosial Ekonomi & 110 & 660 & Potensial \\
2. & Aspek Sosial Budaya & 55 & 330 & Tidak Potensial \\
3. & Aspek Lingkungan & 50 & 300 & Tidak Potensial \\
4. & Aspek Pengelolaan & 80 & 480 & Cukup Potensial \\
\multicolumn{2}{c}{ Rata-rata } & & 442,5 & Cukup Potensial \\
\hline
\end{tabular}

Keterangan : 293 - 426 : Tidak Potensial; 427 - 560 : Cukup Potensial; 561 - 694 : Potensial

Based on the classification in tourism development efforts, Kendran Village has an assessment of the readiness of community-based tourism development which is quite potential. Socio-economic aspects in building community-based tourism development readiness in Kendran Village are potential seen in several aspects such as the market, community economy, use 
of local resources, unit selling, community participation in investment and profit sharing. Socio-cultural and environmental aspects have no potential value, this is more due to the number of criteria used in the development readiness assessment which only includes three principles, namely preservation, appreciation and regulation. Environmental aspects that include environmental management in creating clean and beautiful areas have also been carried out by the community in the form of community service activities. Tourism Village must be understood through two sides, namely Tourism Village from the concept side and Tourism Village from the market side. Tourism Village focuses on three main things, namely natural or ecological sustainability, providing economic benefits, and being psychologically acceptable in the social life of the community.

\section{Kendran Tourism Village Development Strategy}

The development of Kendran Village as a Tourism Village uses a SWOT analysis, namely Strength, Weakness, Oppportunity and Threat to formulate a strategy through mapping the identification of internal and external factors. External factors of opportunity include the support of the local government, positive community attitudes, village locations close to other villages, market opportunities, development of promotional media, stable economic development, adequate infrastructure, development of travel services. Meanwhile, external obstacles that are still being faced are the possibility of social disparities, lack of marketing service capability, inadequate accessibility to villages, sustainability of partnerships, continuity of funding, the impact of pollution and homestay waste, the suitability of community culture, the emergence of modern hotels and villas.

Table 3. SWOT Diagram of the Potential Development of a Tourism Village in Kendran Village [Source: Primary Data, processed, 2019] 


\begin{tabular}{|c|c|c|c|}
\hline $\begin{array}{l}\text { Faktor } \\
\text { Eksternal }\end{array}$ & $\begin{array}{l}\text { Faktor } \\
\text { Internal }\end{array}$ & $\begin{array}{l}\text { STRENGTHS (S) } \\
\text { Faktor kekuatan internal: } \\
\text { 1. Adanya keinginan } \\
\text { masyarakat untuk } \\
\text { berpartisipasi dalam } \\
\text { pengembangan Desa } \\
\text { Wisata } \\
\text { 2. Persepsi positif } \\
\text { masyarakat mengenai } \\
\text { wisata yang } \\
\text { berkelanjutan }\end{array}$ & 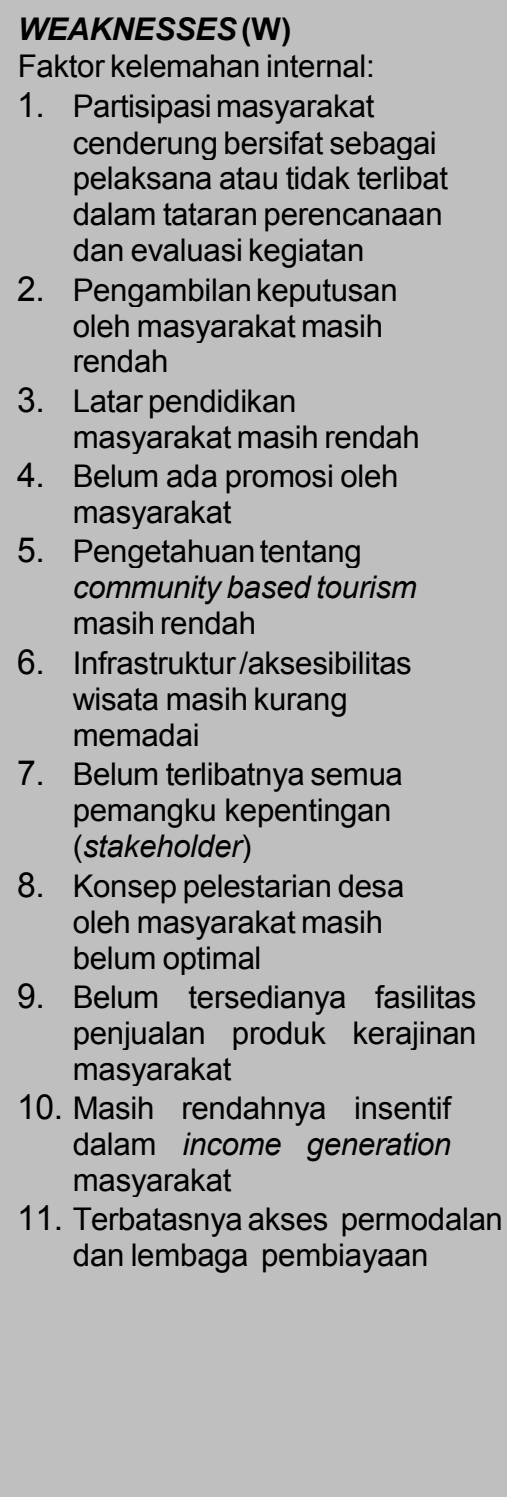 \\
\hline
\end{tabular}


OPPORTUNITIES(O)

Faktor peluang eksternal:

1. Adanya dukungan Pemerintah Daerah dalam mengembangkan Desa Wisata

2. Sikap positif masyarakat dalam menerima program desa wisata

3. Lokasi desa yang berdekatan dengan desa lain yang juga memiliki potensi wisata menjadi paket wisata

4. Peluang pangsa pasar bagi potensi wisata

5. Perkembangan media elektronik dalam menunjang promosi wisata

6. Perkembangan ekonomi dan keamanan yang stabil

7. Infrastruktur yang cukup memadai

8. Berkembangnyajasa biro/agen perjalanan wisata

9. Berkembangnya objek wisata disekitar Desa Kendran

\section{THREATS (T)}

Faktor tantangan eksternal:

1. Kemungkinan adanya disparitas sosial dalam pengembangan desa wisata

2. Kurangnyakemampuan pelayanan pemasaran Desa Wisata

3. Aksesibilitas menuju desa wisata masih kurang memadai

4. Keberlanjutan kemitraan antar stakeholder

5. Kontinuitas pendanaan dalam pengembangan desa wisata

6. Dampak polusi dan limbah hotel atau homestay

7. Kesesuaian budaya masyarakat lokal dan wisatawan asing

8. Mulai berkembangnya hotel dan villa di sektiar Desa Kendran.

\section{Strategi S-O}

Strategi yang menggunakan kekuatan untuk memanfaatkan peluang, yaitu:

1. Keterlibatan masyarakat secara aktif mulai perencanaan hingga pelaksanaan dan evaluasi

2. Pengembangan program desa sesuai potensi budaya lokal

3. Pembentukan media pengelolaan dalam Desa Wisata

4. Promosi program Desa Wisata berbasis masyarakat

.

\section{Strategi W-O}

Strategi yang minimalisir kelemahan untuk memanfaat- kan peluang:

1. Intensifikasipendampingan masyarakat dalam setiap tahapan pengembangan desa wisata

2. Penguatan kelembagaan sosial ekonomi dan budaya masyarakat

3. Pengembangan usaha ekonomi kreatif masyarakat melalui inovasi

4. Memberikan pelatihan dan pemahaman kepada masyrakat tentang arah dan manfaat desa wisata bagi kehidupan masyarakat

\section{Strategi S-T}

Strategi yang menggunakan kekuatan untuk mengatasi ancaman

1.Pengembangan desa yang potensial yang berdekatan dengan Desa Kendran

2. Peningkatan kualitas masyarakat dalam pengelolaan wisata melalui pelatihan teknis dan manajerial

3. Peningkatan kesadaran masyarakat terhadap desa wisata dan lingkungan

4. Penguatan kemitraan antar stakeholder

\section{Strategi W-T}

Strategi yang meminimalisir kelemahan untuk mengatasi ancaman

1. Peningkatan aksesibilitas dan infrastruktur penunjang yang memperhatikan prinsip budaya dan lingkungan 
Seeing the internal and external conditions in the development of the Tourism Village in Kendran Village, a comprehensive and integrative strategy from internal and external positions is needed to strengthen the development of tourism potential. Some of these strategies are: (1) Active community involvement from planning to implementation and evaluation; (2) Development of village programs according to local cultural potential; (3) Establishment of management media in the Tourism Village; (4) Promotion of the communitybased Tourism Village program; (5) potential village development adjacent to Kendran Village; (6) Increasing the quality of the community in tourism management through technical and managerial training; (7) Increasing public awareness of environmental conservation; (8) Strengthening partnerships between stakeholders; (9) intensification of community assistance in every stage of ecotourism development; (10) Strengthening socio-economic and cultural institutions of the community; (11) Developing the community's creative economy through innovation; (12) Increasing accessibility and supporting infrastructure by taking into account ecological principles.

Table 4. Results of Internal Factor Analysis

[Source: Primary Data, processed, 2019]

\begin{tabular}{|c|c|c|c|}
\hline Faktor-Faktor Strategi Internal & Bobot & Skor & Nilai \\
\hline \multicolumn{4}{|l|}{ Kekuatan } \\
\hline $\begin{array}{l}\text { Adanya keinginan masyarakat untuk berpartisipasi dalam } \\
\text { pengembangan Desa Wisata }\end{array}$ & 0,05 & 3,5 & 0,17 \\
\hline Persepsi positif masyarakat mengenai wisata yang berkelanjutan & 0,05 & 3,4 & 0,16 \\
\hline Adanya kesenian tradisional dari budaya lokal & 0,05 & 3,4 & 0,16 \\
\hline Daya tarik desa yang masih alami dengan sawah terasering & 0,05 & 3,5 & 0,17 \\
\hline Produksi hasil kerajinan khas Desa Kendran & 0,05 & 3,6 & 0,18 \\
\hline Adanya objek wisata, berupa peninggalan pra sejarah & 0,05 & 3,5 & 0,17 \\
\hline Adanya objek wisata, berupa puri dan social masyarakat. & 0,05 & 3,5 & 0,17 \\
\hline Adanya objek wisata air terjun, mata air, tempat permandian spritual. & 0,05 & 3,5 & 0,17 \\
\hline $\begin{array}{l}\text { Keterbukaan dan keramahan penduduk yang sebagian besar penduduk } \\
\text { asli terhadap pengunjung }\end{array}$ & 0,05 & 3,7 & 0,19 \\
\hline 10 Adanya motivasi ekonomi bagi masyarakat dengan pengembangan wisata & 0,05 & 3,5 & 0,17 \\
\hline $\begin{array}{l}11 \text { Adanya pengaruh dan kepatuhan masyarakat terhadap tokoh masyarakat } \\
\text { setempat }\end{array}$ & 0,05 & 3,5 & 0,17 \\
\hline \multicolumn{4}{|l|}{ Kelemahan } \\
\hline $\begin{array}{l}1 \text { Partisipasi masyarakat cenderung bersifat sebagai pelaksana atau } \\
\text { tidak terlibat dalam tataran perencanaan dan evaluasi kegiatan }\end{array}$ & 0,04 & 2,8 & 0,11 \\
\hline Pengambilan keputusan oleh masyarakat masih rendah & 0,04 & 2,6 & 0,09 \\
\hline Latar pendidikan masyarakat masih rendah & 0,05 & 3,6 & 0,18 \\
\hline Belum ada promosi oleh masyarakat & 0,04 & 3 & 0,12 \\
\hline Pengetahuan tentang community based tourism masih rendah & 0,05 & 3,8 & 0,20 \\
\hline Infrastruktur /aksesibilitas wisata masih kurang memadai & 0,05 & 3,7 & 0,19 \\
\hline Belum terlibatnya semua pemangku kepentingan (stakeholder) & 0,03 & 2,5 & 0,08 \\
\hline Konsep pelestarian desa oleh masyarakat masih belum optimal & 0,05 & 3,5 & 0,17 \\
\hline Belum tersedianya fasilitas penjualan produk kerajinan masyarakat & 0,04 & 2,6 & 0,09 \\
\hline 10 Masih rendahnya insentif dalam income generation masyarakat & 0,05 & 3,5 & 0,17 \\
\hline 11 Terbatasnya akses permodalan dan lembaga pembiayaan & 0.05 & 3,4 & 0,16 \\
\hline Jumlah & 1 & & 3,39 \\
\hline
\end{tabular}


Based on the results of the identification of the development of the Tourism Village in Kendran Village based on the community, the external factors of opportunity are greater than the threat factors. This condition shows that the tourism potential of Kendran Village is quite potential in capturing external opportunities in facing all possible external threats that can arise at any time.

Table 5. Results of External Factor Analysis

[Source: Primary Data, processed, 2019]

\begin{tabular}{|c|c|c|c|c|}
\hline \multicolumn{2}{|r|}{ Faktor-Faktor Strategi Eksternal } & Bobot & Skor & Nilai \\
\hline 1 & $\begin{array}{l}\text { Adanya dukungan Pemerintah Daerah dalam mengembangkan } \\
\text { desa Desa Wisata }\end{array}$ & 0,06 & 3,8 & 0,24 \\
\hline 2 & Sikap positif masyarakat dalam menerima program desa wisata & 0,06 & 3,7 & 0,23 \\
\hline 3 & $\begin{array}{l}\text { Lokasi desa yang berdekatan dengan desa lain yang juga } \\
\text { memiliki potensi wisata }\end{array}$ & 0,06 & 3,6 & 0,22 \\
\hline 4 & Peluang pangsa pasar bagi potensi wisata & 0,04 & 2,4 & 0,10 \\
\hline 5 & Perkembangan media elektronik dalam menunjang promosi wisata & 0,06 & 3,8 & 0,24 \\
\hline 6 & Perkembangan ekonomi dan keamanan yang stabil & 0,06 & 3,7 & 0,23 \\
\hline 7 & Infrastruktur yang cukup memadai & 0,06 & 3,7 & 0,23 \\
\hline 8 & Berkembangnya jasa biro/agen perjalanan wisata & 0,06 & 3,5 & 0,21 \\
\hline 9 & Berkembangnya objek wisata disekitar Desa Kendran & 0,06 & 3,3 & 0,18 \\
\hline \multicolumn{5}{|c|}{ Ancaman } \\
\hline 1 & $\begin{array}{l}\text { Kemungkinan adanya disparitas sosial dalam pengembangan } \\
\text { desa wisata }\end{array}$ & 0,06 & 3,5 & 0,21 \\
\hline 2 & Kurangnya kemampuan pelayanan pemasaran Desa Wisata & 0,06 & 3,4 & 0,19 \\
\hline 3 & Aksesibilitas menuju desa wisata masih kurang memadai & 0,06 & 3,5 & 0,21 \\
\hline 4 & Keberlanjutan kemitraan antar stakeholder & 0,06 & 3,4 & 0,19 \\
\hline 5 & Kontinuitas pendanaan dalam pengembangan desa wisata & 0,06 & 3,4 & 0,19 \\
\hline 6 & Dampak polusi dan limbah hotel atau homestay & 0,06 & 3,5 & 0,21 \\
\hline 7 & Kesesuaian budaya masyarakat lokal dan wisatawan asing & 0,06 & 3,6 & 0,22 \\
\hline \multirow[t]{2}{*}{8} & Mulai berkembangnya hotel dan villa di sektiar Desa Kendran & 0,06 & 3,5 & 0,21 \\
\hline & Jumlah & 1 & & 3,52 \\
\hline
\end{tabular}

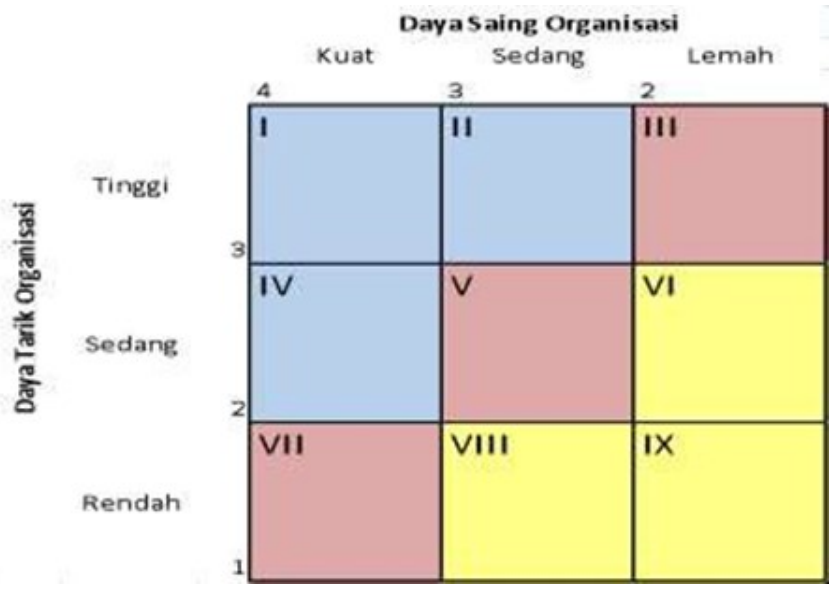

Figure 1. Strategic Position of Kendran Tourism Village Development

The results of the internal and external analysis (IFAS and EFAS) are then included in the Internal External Matrix or often called the IE Matrix. In the 
IE matrix there are nine cells with the following strategy implementation Growth and Build strategies are applied if the organization's position is in cells I, II, and IV, the Hold and Maintain strategy is applied if the organization's position is in cells III, V, and VII; and the Harvest or Diverst strategy is applied when the position of the organization is in cells VI, VIII, and IX (David, 2006). Based on internal and external analysis, it is known that the IFAS weighted average value of tourism village development in Kendran Village is 3.39 and the EFAS weighted average value is 3.52 and its position in the IE Matrix is in Cell I (see Figure 1).

This means that Kendran Village has a strong category competitiveness and high category appeal as a tourist village, so the position of the Kenderan tourism village development strategy is in a Growth and Build condition.

Intensive strategies that can be applied to the development of Kenderan tourism village, namely (1) Market penetration strategy, namely a strategy to seek a wider market share for the tourism potential of Kendran Village that already exists today through more active marketing efforts; (2) Product development strategy, which is a strategy that seeks to increase income by managing existing tourist objects or developing new tourist objects.

\section{Stakeholders who Role in the Development of a Tourism Village in Bali}

Actors/stakeholders are an important component that determines how sustainability goals are achieved, and also determines the factors that become the basis for sustainability (Fauzi, 2019). Analysis using the MACTOR method (Matrix of Alliance, Conflicts, Tactics, Objectives, and Recommendations) conducts a strength analysis (relative strength) between factors or stakeholders and explores the similarities and differences to the various problems and objectives to be achieved (Bendahan et al., 2003). In addition, several objectives (objectives) were grouped as shown in Table 7.

Table 6. Identification of Actors / Stakeholders Related to the Development of Kendran Tourism Village, Gianyar Regency, Bali Province

\begin{tabular}{rlll}
\hline No & StakeholderlAktor & \multicolumn{1}{c}{ Kode } & \multicolumn{1}{c}{ Deskripsi } \\
1. & Masyarakat Setempat & Masyarakat & $\begin{array}{l}\text { Masyarakat yang bertempat tinggal di Desa } \\
\text { Wisata Kendran }\end{array}$ \\
2. Pemerintah Pusat & Pem.Pusat & $\begin{array}{l}\text { Pemerintah Pusat dan lembaga pusat terkait pariwisata } \\
\text { 3. } \begin{array}{l}\text { Pemerintah Provinsi } \\
\text { Bali }\end{array}\end{array}$ & $\begin{array}{l}\text { Pem.Prov } \\
\text { terkait pariwisata di Provinsi Bali }\end{array}$ \\
\hline
\end{tabular}




\begin{tabular}{|c|c|c|c|}
\hline 4. & $\begin{array}{l}\text { Pemerintah } \\
\text { Kabupaten Gianyar }\end{array}$ & Pem.Kab & $\begin{array}{l}\text { Pemerintah Kabupaten Gianyar, khususnya } \\
\text { instansi terkait pariwisata di Kabupaten Gianyar }\end{array}$ \\
\hline 5. & $\begin{array}{l}\text { Pemerintah Desa } \\
\text { Kendran }\end{array}$ & Pem.Desa & Pemerintah Desa Kendran serta aparaturnya \\
\hline 6. & $\begin{array}{l}\text { Sektor lembaga } \\
\text { pariwisata swasta }\end{array}$ & Swasta & Lembaga swasta yang menyediakan jasa pariwisata \\
\hline 7. & $\begin{array}{l}\text { Pelaku wisata swasta } \\
\text { di Desa Kendran }\end{array}$ & Sw.Kendran & $\begin{array}{l}\text { Pelaku wisata swasta yang menyelenggarakan } \\
\text { kegiatan pariwisata di Desa Kendran (seperti villa, } \\
\text { hotel, tracking, cycling) }\end{array}$ \\
\hline 8. & Desa Adat setempat & Desa Adat & Desa Adat di lingkungan Desa Wisata Kendran \\
\hline 9. & $\begin{array}{l}\text { Pokdarwis Desa } \\
\text { Wisata Kendran }\end{array}$ & Pokdarwis & Pokdarwis pada Desa Wisata Kendran \\
\hline
\end{tabular}

Table 7. Identification of Goals / Objectives related to the Development of Kendran Tourism Village, Gianyar Regency, Bali Province

\begin{tabular}{|c|c|c|c|}
\hline No & Objective/Tujuan & Kode & Deskripsi \\
\hline 1. & $\begin{array}{l}\text { Peningkatan } \\
\text { Ekonomi }\end{array}$ & Ekonomi & $\begin{array}{l}\text { Pengembangan Desa Wisata Kendran utuk } \\
\text { peningkatan ekonomi masyarakat }\end{array}$ \\
\hline 2. & $\begin{array}{l}\text { Pengembangan } \\
\text { Pariwisata }\end{array}$ & Pariwisata & $\begin{array}{l}\text { Pengembangan Desa Wisata Kendran utuk } \\
\text { pengembangan pariwisata di Desa Kendran dan }\end{array}$ \\
\hline 3. & $\begin{array}{l}\text { Pemberdayaan } \\
\text { Masyarakat }\end{array}$ & $\begin{array}{l}\text { Pember- } \\
\text { dayaan }\end{array}$ & $\begin{array}{l}\text { Pengembangan Desa Wisata Kendran utuk } \\
\text { pemberdayaan masyarakat Desa Kendran }\end{array}$ \\
\hline 4. & $\begin{array}{l}\text { Peningkatan Sarana } \\
\text { dan Prasarana }\end{array}$ & Sarpras & $\begin{array}{l}\text { Pengembangan Desa Wisata Kendran utuk } \\
\text { peningkatan sarana dan prasarana umum di Desa }\end{array}$ \\
\hline 5. & $\begin{array}{l}\text { Konservasi Alam } \\
\text { dan Lingkungan }\end{array}$ & Alam & Konservasi alam dan lingkungan di Desa Wisata Kendran \\
\hline 6. & Pelestarian Budaya & Budaya & Pelestarian seni dan budaya di Desa Kendran \\
\hline
\end{tabular}

The results of data analysis with MACTOR software show the MDII (Matrix of

Direct and Indirect Influence) results as shown in Table 8 below.

Table 8. MDII Related to Kendran Tourism Village Development Map of influences and dependences between actors

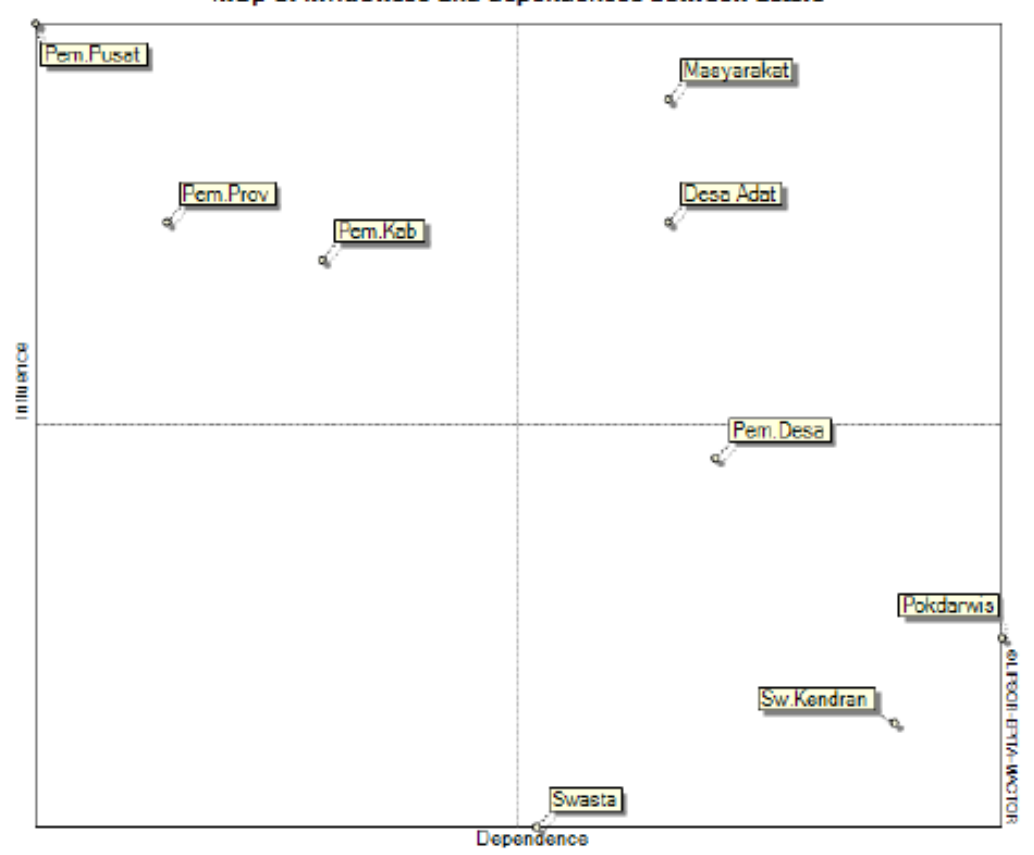

Figure 2. Interactor Map 
Based on Table 8, it can be seen that the central government is the most influential stakeholder, while the most dependent stakeholder is pokdarwis. This is in accordance with the facts on the ground that developing tourism villages requires regulatory support and sarpras, so that budgets and policies need to be synchronized starting from the central level. Meanwhile, pokdarwis very much depends on the condition and treatment of other stakeholders. Figure 2 shows a map of the influence and dependence between the factors. Based on Figure 2, it is known that the central government, provincial governments, and district governments are in quadrant I, which means that the influence is high. Meanwhile, other actors, namely the private sector, local farmers, and local tourism institutions tend to experience dependence. Table 6.9 below presents the results of the $1 \mathrm{MAO}$ (actor-objective) analysis.

Table 9. Results of $1 \mathrm{MAO}$ Analysis

\begin{tabular}{|c|c|c|c|c|c|c|c|}
\hline $1 \mathrm{MAO}$ & 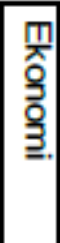 & 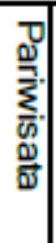 & 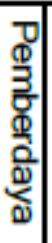 & $\begin{array}{l}0 \\
0 \\
\overline{0} \\
0 \\
0\end{array}$ & $\frac{d}{3}$ & 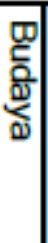 & 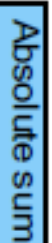 \\
\hline Masyarakat & 1 & 1 & 1 & 1 & 1 & 1 & 6 \\
\hline Pem.Pusat & 1 & 1 & 1 & 1 & 1 & 1 & 6 \\
\hline Pem.Prov & 1 & 1 & 1 & $T$ & 1 & 1 & 6 \\
\hline Pem.Kab & 1 & 1 & 1 & 1 & 1 & 1 & 6 \\
\hline Pem.Desa & 1 & 1 & 1 & 1 & T & 7 & 6 \\
\hline Swasta & 1 & 1 & $\overline{0}$ & 1 & 1 & 1 & 5 \\
\hline Sw.Kendran & 1 & 1 & 1 & T & 1 & T & 6 \\
\hline Desa Adat & 1 & $\mid$ & 1 & 1 & 1 & 1 & 6 \\
\hline Pokdarwis & 7 & 1 & 1 & 1 & 7 & 1 & 6 \\
\hline Number of agreements & 9 & 9 & $\overline{8}$ & $\overline{9}$ & $\overline{9}$ & $\overline{9}$ & \\
\hline Number of disagreements & 0 & 0 & 0 & 0 & 0 & 0 & \\
\hline Number of positions & 9 & 9 & 8 & 9 & 9 & $\overline{9}$ & \\
\hline
\end{tabular}

In general, it appears that all actors agree with the objectives or objectives described. This can be seen from the score of +1 on all actors for their respective objectives. Furthermore, Table 10 presents the analysis of convergence (2CAA) between factors (valued convergence). It can be seen that the government and tourism agencies have the same interest with an intensity of 12.0. This is consistent with the facts on the ground that the government is the determinant of regulations and the provision of facilities and infrastructure, 
while local tourism institutions are the spearhead of implementing agro-tourism development programs in Kendran Tourism Village.

Table 10. 2CAA Analysis Results and Table 11 Weighted Value Matrix for Actor Position(3MAO)

\begin{tabular}{|c|c|c|c|c|c|}
\hline 2CAA & $\frac{3}{3}$ & 8 & $\frac{3}{3}$ & 变 & $\frac{\gtrless}{\xi}$ \\
\hline AMS & 0.0 & 10.0 & 11.0 & 10.5 & 11.0 \\
\hline APS & 10.0 & 0.0 & 11.0 & 10.5 & 11.0 \\
\hline APM & 11.0 & 11.0 & 0.0 & 11.5 & 12.0 \\
\hline ASW & 10.5 & 10.5 & 11.5 & 0.0 & 11.5 \\
\hline ALW & 11.0 & 11.0 & 12.0 & 11.5 & 0.0 \\
\hline Number of comvergences & 42.5 & 425 & 45.5 & 44.0 & 45.5 \\
\hline Degroe of convernence (\%) & 100.0 & & & & \\
\hline
\end{tabular}

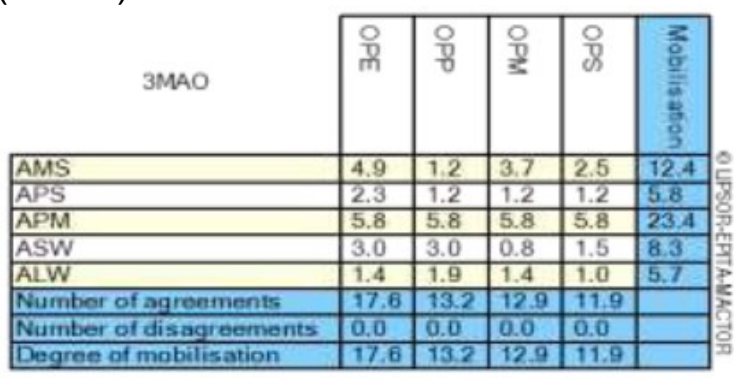

The 3MAO matrix provides an overview of the most active factors, namely the government and local communities with mobilization scores of 23.4 and 12.4, respectively. Meanwhile, the degree of mobilization of 17.6 (line degree of mobilization) shows that economic improvement is the goal that activates the most actors.

This is also seen in Figure 3 , where the number of degrees of mobilization of 17.6 for economic improvement is the highest, followed by tourism development, community empowerment, and improvement of facilities and infrastructure.

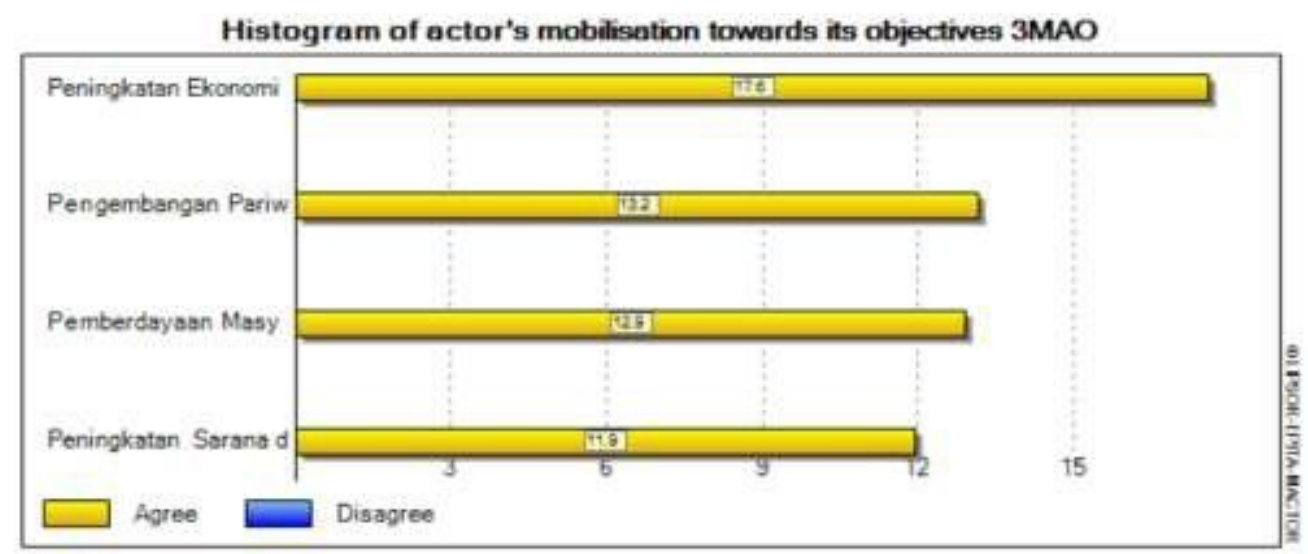

Figure 3. The Mobility of Actors Against Objectives Histogram

Broadly speaking, it is known that in this case there is no divergence between actors so that ambivalence between factors also does not occur, as illustrated in Figure 4.Figure 4 shows the balance between the pros and cons of each objective showing that the scales are all heavier to the mark $(+)$. 
MULTIPOL is a multicriteria-based policy analysis tool (Fauzi, 2019). The average score measures the overall performance of each action against the policy (or program against the policy), while the standard deviation value shows the sensitivity of each action to the policy (Stratigea et al., 2013).

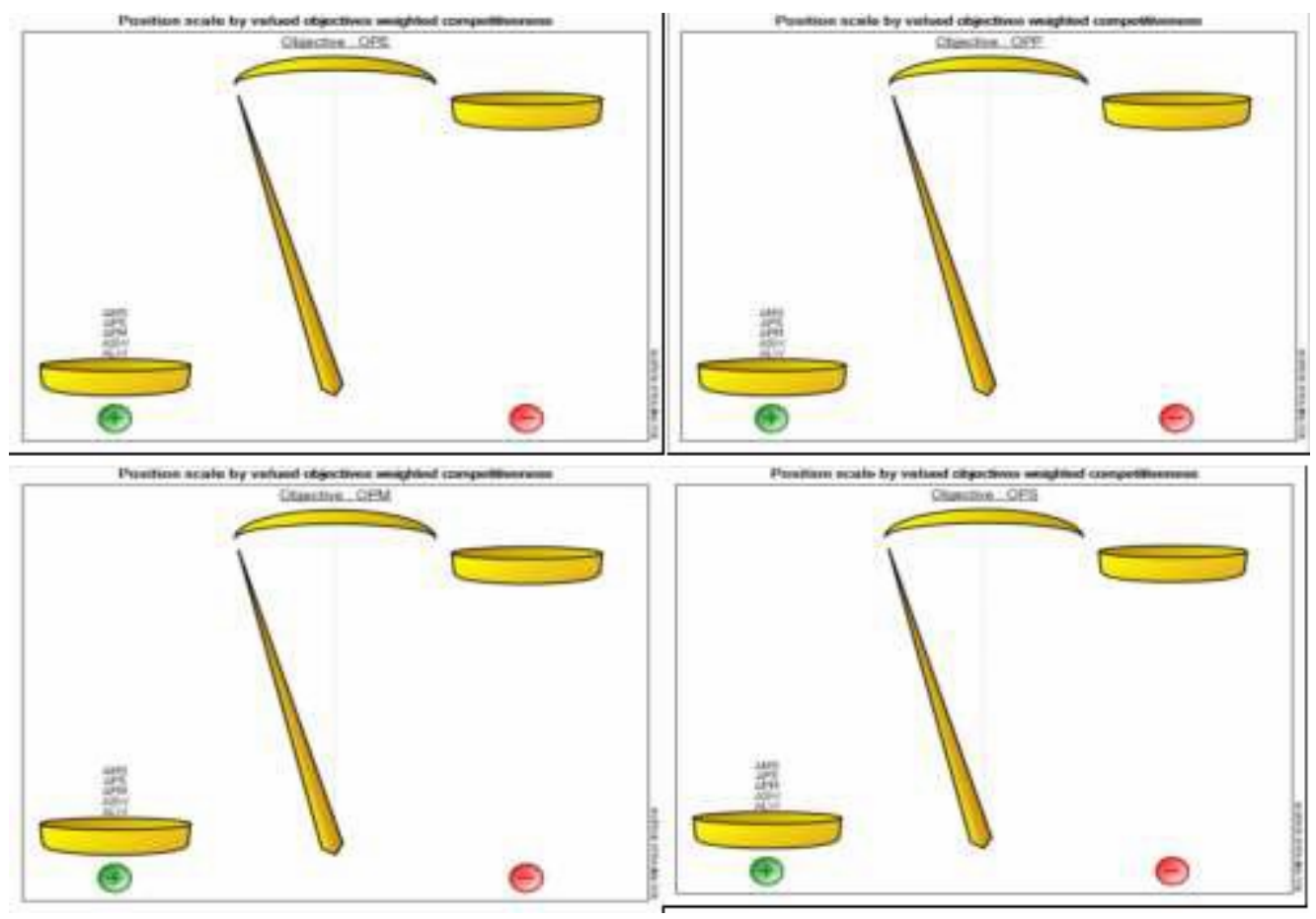

Figure 4. The position of the pros and cons of each objective

Table 12. Scenarios, Criteria, Policy, and Action for the Development of Tourism Villages in Bali

\begin{tabular}{|c|c|c|}
\hline A. & Scenario & Kode \\
\hline 1. & Desa Wisata Single Destination & DW Single \\
\hline 2. & Desa Wisata Multiple Destination & DW. Multip \\
\hline B. & Criteria & Kode \\
\hline 1. & Peningkatan ekonomi dan pendapatan & Ekonomi \\
\hline 2. & Penyerapan tenaga kerja & T. kerja \\
\hline 3. & Tumbuhnya usaha baru & Usaha \\
\hline 4. & Konservasi alam/lingkungan & Alam \\
\hline 5. & Peningkatan infrastruktur & Infra \\
\hline 6. & Pelestarian budaya & Budaya \\
\hline C. & $\begin{aligned} \text { Policy }\end{aligned}$ & Kode \\
\hline 1. & Peningkatan kapasitas masyarakat desa & Kapasitas \\
\hline 2. & Penguatan kelembagaan desa wisata & Lembaga \\
\hline 3. & Pengemasan atraksi/daya tarik wisata & DTW \\
\hline 4. & Penciptaan branding & Brand \\
\hline 5. & Perluasan dan pemeliharaan pasar & Pasar \\
\hline D. & 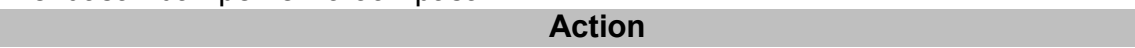 & Kode \\
\hline 1. & Sosialisasi desa wisata & Sosialisasi \\
\hline 2. & Pelatihan ToT (Trainning of Trainer) dan CO (Community Organizer) desa wisata & Pelatihan \\
\hline 3. & $\begin{array}{l}\text { Serial trainning pengelolaan desa wisata (local guide, homestay, kuliner/F\&B, } \\
\text { atraksi desa wisata) }\end{array}$ & Serial T. \\
\hline 4. & Penyusunan dan penataan regulasi terkait & Regulasi \\
\hline 5. & Penataan organisasi desa wisata & Organisasi \\
\hline 6. & Menyiapkan manajemen atraksi (pengemasan paket atraksi desa wisata, harga, & Man.Atrak \\
\hline
\end{tabular}




\begin{tabular}{cll}
\hline 7. & Spesialisasi keunikan produk (wisata, kerajinan, kesenian, OVOP) & Spesialisa \\
8. & Membentuk jaringan promosi wisata & Promosi \\
9. & Memasarkan produk wisata secara online & Online \\
\hline
\end{tabular}

Table 13. Evaluation Based on Actions and Policy

\begin{tabular}{|c|c|c|c|c|c|c|c|c|}
\hline \multirow[b]{2}{*}{ Actions } & \multicolumn{5}{|c|}{ Policy } & \multirow{2}{*}{$\begin{array}{c}\text { Nilai rerata } \\
\text { (mean value) }\end{array}$} & \multirow{2}{*}{$\begin{array}{c}\text { Simpangan } \\
\text { Baku }\end{array}$} & \multirow[b]{2}{*}{ Posisi } \\
\hline & Kapasitas & Lembaga & DTW & Brand & Pasar & & & \\
\hline Sosialisasi & 13.2 & 13.7 & 13.8 & 13 & 13.1 & 13.3 & 0.3 & 9 \\
\hline Pelatihan & 12.3 & 11.9 & 12.1 & 10.7 & 11.9 & 11.8 & 0.6 & 6 \\
\hline Serial T. & 12.3 & 11.9 & 12.4 & 10.8 & 12.1 & 11.9 & 0.6 & 7 \\
\hline Regulasi & 12.8 & 12.5 & 12.8 & 11.8 & 12.7 & 12.5 & 0.4 & 8 \\
\hline Organisasi & 10.2 & 10 & 10.1 & 9.6 & 10.1 & 10 & 0.2 & 2 \\
\hline Man.Atraksi & 10.5 & 10.6 & 10.5 & 10.3 & 10.4 & 10.4 & 0.1 & 3 \\
\hline Spesialisasi & 12.1 & 11.7 & 12.2 & 10.7 & 11.7 & 11.7 & 0.6 & 5 \\
\hline Promosi & 10.8 & 10.4 & 10.8 & 10.1 & 10.6 & 10.6 & 0.3 & 4 \\
\hline Online & 8.4 & 7.5 & 8.3 & 6.5 & 7.7 & 7.7 & 0.7 & 1 \\
\hline
\end{tabular}

As seen in Table 13, the highest score was obtained in the tourism village socialization activities (Socialization), the preparation and arrangement of related regulations (Regulation), and the tourism village management training series (Serial T.). Furthermore, Figure 5 below presents the results of MULTIPOL in the form of a closeness map or the closeness between programs (actions) and policies (policies).
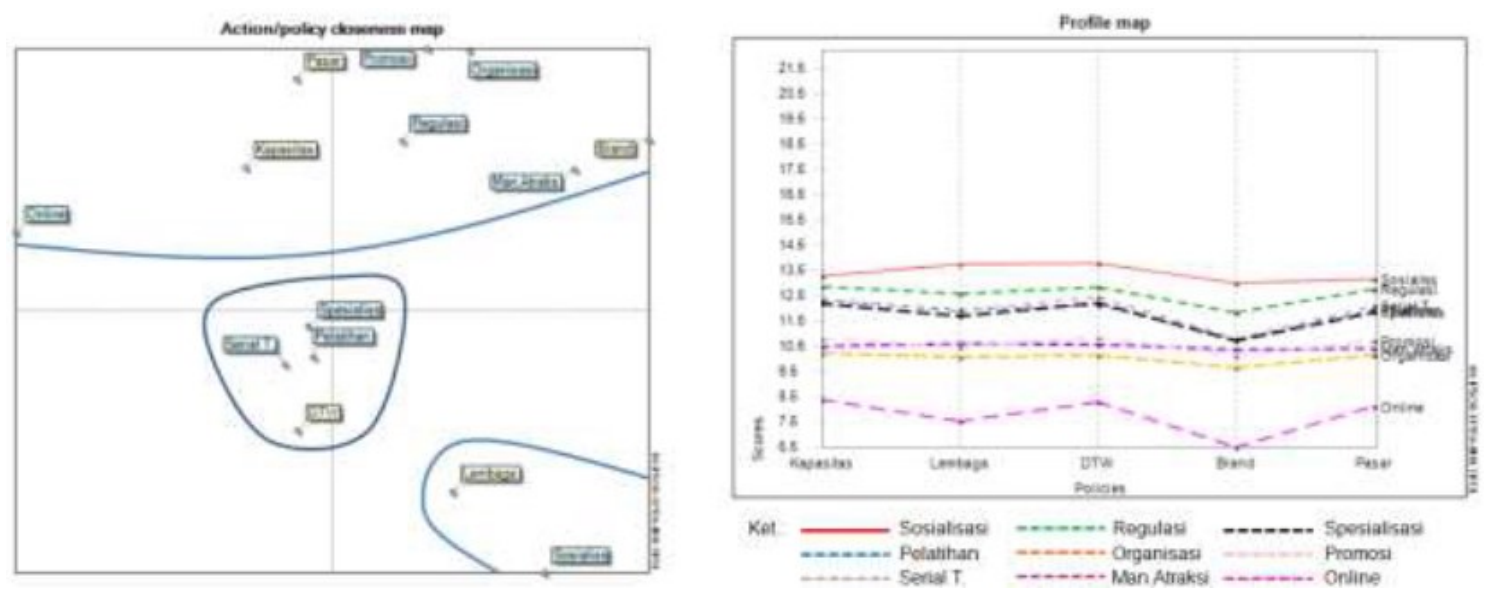

Figure 5 Linkage of Policy and Action (Closeness Map), Figure 6. Profile Map of Tourism Village Development

Based on Figure 5, it is found that policies for increasing the capacity of rural communities, creating branding, and expanding and maintaining markets are closer to the activities of compiling and structuring related regulations, structuring tourism village organizations, preparing attraction management, forming tourism promotion networks, and marketing tourism products online. 
For attractions packaging policies, tourism attractions that are closer are ToT and $\mathrm{CO}$ training programs for tourist villages, training series on tourism village management, and specialization of product uniqueness. Lastly is the policy of strengthening tourism village institutions that are close to the tourism village socialization program.

Based on Figure 6, the tourism village socialization program and the preparation and arrangement of regulations are superior in all types of policies. This is because socialization is a mandatory activity in every policy so that people are not resistant to a policy. Likewise, regulatory harmonization is very important for policy implementation, both from the central level to the village level.

Table 14. Scores of Policy Against Scenarios

\begin{tabular}{|c|c|c|c|c|c|}
\hline Policy & $\begin{array}{c}\text { Desa Wisata } \\
\text { Single } \\
\text { Destination }\end{array}$ & $\begin{array}{l}\text { Desa Wisata } \\
\text { Multiple } \\
\text { Destination }\end{array}$ & $\begin{array}{l}\text { Nilai } \\
\text { Rerata }\end{array}$ & $\begin{array}{l}\text { Simpang- } \\
\text { an Baku }\end{array}$ & Posisi \\
\hline $\begin{array}{l}\text { Peningkatan kapasitas } \\
\text { masyarakat desa }\end{array}$ & 15.4 & 18.7 & 17.5 & 1.6 & 5 \\
\hline Penguatan kelembagaan desa & 16.5 & 17.4 & 17 & 0.4 & 2 \\
\hline Pengemasan atraksi/daya tarik & 16 & 18.1 & 17.3 & 1 & 3 \\
\hline Penciptaan branding & 17.4 & 15.5 & 16.2 & 0.9 & 1 \\
\hline Perluasan dan pemeliharaan & 15.8 & 18.3 & 17.4 & 1.2 & 4 \\
\hline
\end{tabular}

Based on Table 14 and Figure 7, it appears that the policy to increase the creation of superior branding in the single destination tourism village scenario, while the policy to increase the capacity of rural communities has the highest value in the multiple destination tourism village scenario. When viewed from the average value of the two scenarios, the best position is obtained in the policy of increasing the capacity of the village community, then followed by the policy of expanding and maintaining the market and packaging of tourist attractions. 


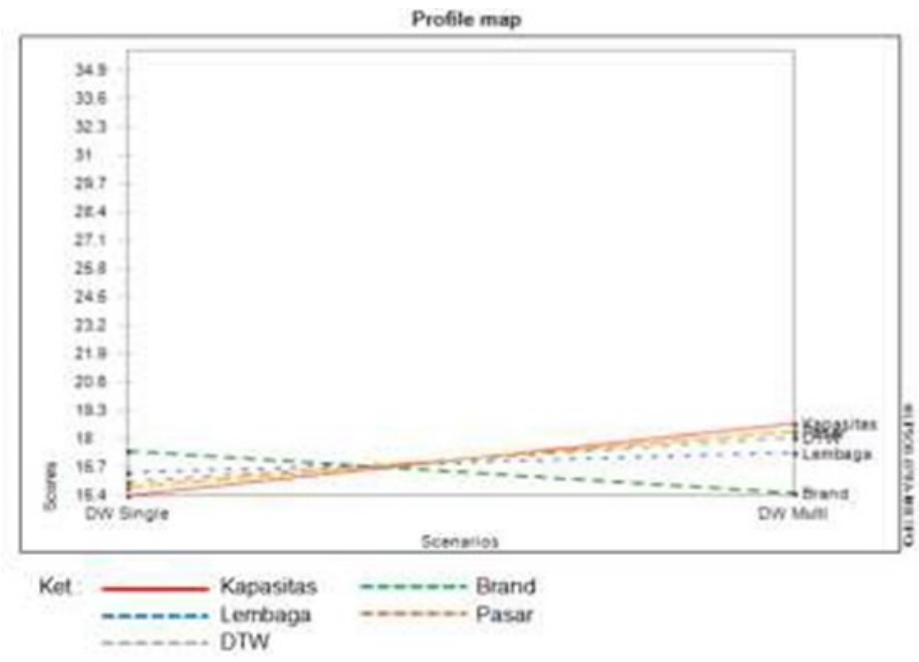

Figure 7. Profile Map for Policy Against Scenarios

If the government will implement a single destination tourism village scenario, the first policy that needs to be implemented is the creation of branding. This shows that if a tourist village is to be developed into a single destination, then the tourist village must have a strong brand and be supported by tourist attractions that meet the overall needs of tourists. Meanwhile, the development of multiple destination tourist villages by linking tourist villages in one area, so that each village supports each other. For the development of multiple destination tourism villages, the main policy that needs to be implemented is to increase the capacity of village communities. 


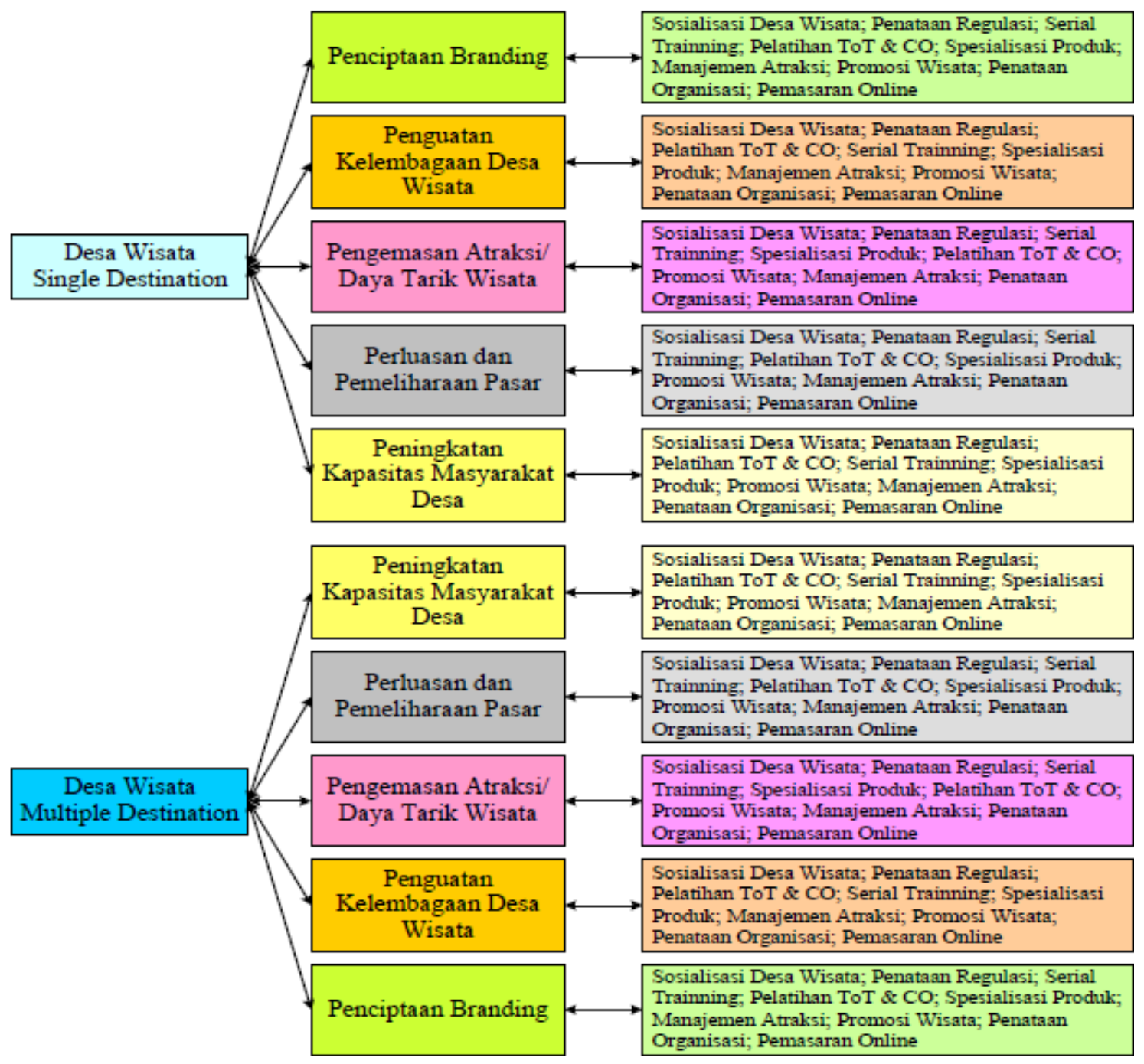

Figure 8. Potential Policy Paths and Programs

\section{Tourism Village Model in Bali}

The Ministry of Tourism has indeed set a tourist village model as a single destination. Where a single destination tourism village must have a tourist unit and packaged in a tour package. So that tourists can visit and stay in the tourist village. On the other hand, every village in Bali has its own potential, and it is hoped that they can support and cooperate with each other, especially for tourist villages that are located side by side. Therefore, multiple destination tourist villages are also an alternative that can be chosen if the brand is not strong. Tourism villages have a main concept of sustainability, including for tourist villages in Bali. Therefore, there are several aspects related to the sustainability of tourism villages that need to be emphasized in the tourist village model in Bali, both for development as a single destination as well as 
multiple destinations. In accordance with the opinion of Schouten (1992), sustainable tourism development focuses on three important points, namely Quality of the experience (customers), Quality of the resources (culture and natural environment), and Quality of life (for local people). . In the concept of sustainable tourism, the focus is on cooperation between tourists and local communities, and the needs of local communities in tourism management planning. The tourism development policy in Bali Province refers to the concept of sustainable and quality tourism, through various multisector policies. These policies are designed to answer various conceptual and factual challenges that exist. Conceptually, the discourse of global tourism is experiencing a paradigmatic turn, from the perspective of mass tourism towards alternative tourism. That is, the style of mass tourism which focuses on the logic of growth (increasing the number of tourist visits) as a measure of the success of tourism, shifts its orientation to the logic of sustainability and distribution of tourism resources.

The basis and basic framework for tourism development in the Province of Bali is cultural richness and environmental sustainability (pro culture and pro environment). This policy gives more preference and facilitates investment based on agro tourism and nature tourism or the agricultural and handicraft sector that supports sustainable tourism. The Province of Bali in developing its tourism products pays attention to two things, namely the tourism market trend and remains in the corridor of developing tourism products based on local resources.

\section{CONCLUSION}

Assessment of the object and attractiveness of Kendran Village includes several elements of assessment, namely aspects of tourist attraction, accessibility, socio-economic environmental conditions, accommodation and supporting infrastructure. Based on the results of the assessment of the elements of the tourist attraction of Kendran Village, the average value of the assessment of the attractiveness of the Kendran Village tourism object is categorized as quite potential. Assessment of the readiness of developing a community-based tourism village (Community Based Tourism) is divided into four aspects of the assessment, namely socio-economic aspects, socio-cultural 
aspects, environmental aspects and management aspects. Based on the results of the assessment of the readiness of the development of the Kenderan Tourism Village, the average value of the development readiness of Kendran Village is quite potential.

Internal factors in the development of Kendran Tourism Village which are the strengths possessed include the desire of the community to participate, positive perceptions of sustainable tourism, the existence of traditional arts and local culture, the attractiveness of villages with terraces, springs, waterfall tours, spiritual tourism, and castle tourism, handicraft production, openness and friendliness of the population and the existence of community economic motivation in developing the Tourism Village, community obedience to traditional leaders. While internal factors in the form of weakness are community participation tends to be the implementer, community decision making is still low, education is low, there is no promotion, knowledge of community based tourism is still low, tourism infrastructure is inadequate, all stakeholders have not been involved, the concept of village conservation is not optimal, not yet there is a place to sell souvenirs, incentives are still low and access to capital is limited.

External factors that are opportunities in the development of Kendran Tourism Village include the support of the Regional Government, positive community attitudes, village locations close to other villages, market opportunities, development of promotional media, stable economic development, adequate infrastructure, development of travel services. . Meanwhile, external obstacles that are still faced are the possibility of social disparities, lack of marketing service capability, inadequate accessibility to villages, sustainable partnerships, continuity of funding, the impact of pollution and homestay waste, the suitability of community culture, the emergence of modern hotels and villas.

Based on the identification results of the development of the Tourism Village in Kendran Village, the strength factor that is owned is still greater than the weakness. Likewise, the opportunity for external factors is greater than the threat factor. Based on the results of the analysis, it is known that Kendran Village has a strong category competitiveness, and high category attractiveness as a tourist village, so that the position of the Kenderan tourism village 
development strategy is in a condition of Growth and Build. Seeing the internal and external conditions in the development of the Tourism Village in Kendran Village, a comprehensive and integrative strategy from internal and external positions is needed to strengthen the development of tourism potential.

There are various stakeholders related to the development of Kendran Tourism Village, as well as tourism villages in Bali in general, such as the local community, the government (central / province / district / city / village), tourism actors, the private sector, elements of traditional villages, and pokdarwis. The results of the analysis show that indeed all stakeholders have a positive interest in the development of a tourist village, so it is very possible for the government to initiate cooperation between various stakeholders.

The tourism village model which is a scenario in the development of a tourist village is a single destination tourism village and a multiple destination tourist village. Meanwhile, several main policies that need to be prioritized include increasing the capacity of rural communities, strengthening tourism village institutions, packaging tourist attractions / attractions, creating branding, and expanding and maintaining markets. For the development of a single destination tourism village, the main policy that needs to be developed is the creation of branding, while the policy to increase the capacity of rural communities has the highest value in the multiple destination tourism village scenario.

The tourism development policy in Bali Province refers to the concept of sustainable and quality tourism, through various multisector policies. These policies are designed to answer various conceptual and factual challenges that exist. Conceptually, the discourse of global tourism is experiencing a paradigmatic turn, from the perspective of mass tourism towards alternative tourism. That is, the style of mass tourism which focuses on the logic of growth (increasing the number of tourist visits) as a measure of the success of tourism, shifts its orientation to the logic of sustainability and distribution of tourism resources.

More technically, the following can be recommended: A tourism village policy implementation framework is needed for the provincial and district / city governments of Bali to be able to formulate and realize tourism villages as part of alternative tourism in a sustainable manner. 
Efforts to propose a Draft Regional Regulation (Ranperda) on tourism in the Province of Bali, which includes a tourism village, in order to overcome multiple interpretations of the meaning, criteria, classification and capital of tourism villages.

Socialization of Tourism Villages as alternative tourism based on community participation because the understanding in the tourism village community is precisely as mass tourism, in collaboration with university service activities.

Assistance is needed for tourist villages by the Provincial Government and District / City Governments in collaboration with NGOs and experienced universities / academics, in order to oversee the process of internalizing the mind-set of tourist villages and overcoming feelings of abandonment / abandonment that afflicts most Pokdarwis administrators by other stakeholders.

The young generation in tourist villages must be considered so that they are aware of the existence of tourist villages, so they do not leave their villages to look for work. As far as possible, tourism products from tourism villages are related or synergized according to existing potential, in order to avoid overlapping and monotony of the tourism products offered.

Strengthening the tourism village network driven by the Tourism Awareness Group (Pokdarwis) in each tourism village by intensively cooperating and promoting with the tourism industry (PHRI, ASITA), universities, and other developed tourism villages in other areas. Strengthening capital and human resources by establishing a legal tourism foundation. Increase the enthusiasm and passion of the villages for the creation of a tourism village in a bottom-up manner, by holding village tourism competitions facilitated by the Badung Regency Government, and assessed and evaluated by experienced colleges / academics and according to competence.

A study is needed in the form of research on marketing strategies with special segmentation in collaboration with stakeholders, including the idea of strengthening local tourism activities with educational tourism creations involving the participation of schools in Bali Province. 
It is very urgent to carry out further research regarding the policies of the Bali Provincial Government and District / City Governments related to the Development of Tourism Villages, based on the Detailed Spatial Plan (RDTR) of the Province of Bali, so that the development of tourism villages does not conflict with the RDTR.

Further research is needed on strengthening tourism village institutions in Bali Province / Regency / City, in order to overcome operational, cultural and structural obstacles.

\section{REFERENCES}

Choy, D.L. 1997. Perencanaan Wisata. Belajar dari Pengalaman di South East Queesland. Proceedings on The Planning and Workshop of Planning Sustainable Tourism. Penerbit ITB Bandung.

Darmawan, I Putu Ikka; Ni Wayan Ardini; I Gede Mudana. 2020. Kecak Touristic Performance in Uluwatu Temple: Its Aspects of Vocal Karawitan. Jurnal Bali Membangun Bali, Volume 1, Nomor 1, April 2020. Dikutip dari:

http://ejournal.baliprov.go.id/index.php/jbmb/article/view/109

Departemen Kebudayaan dan Pariwisata dan WWF-Indonesia. 2009. Prinsip dan Kriteria Wisata Berbasis Masyarakat. Direktorat Jenderal Pengembangan Destinasi Pariwisata. Januari.

Elfianita, E. 2011. Pengembangan Pariwisata Berbasis Community Based Tourism (CBT) di Desa Wisata Limbasari Kecamatan Bobotsari, Kabupaten Purbalingga, Jurnal UNY.

Fandeli, C. dan Mukhlison. 2000. Pengusahaan Wisata. Yogyakarta: UGM.

http://desakendran.blogspot.com/2014/08/sda-danorbitasi.html http://www.bali.bisnis.com

http://www.parekraf.go.id https://id.wikipedia.org/wiki/ Kendran,Tegallalang,Gianyar 
Jeffries, D. J.. Butterworth Heinemann. 2001. Governments and tourism. International Journal of Tourism Research, Volume 4, Issue 6, pages 487-488.

Juniartini, Ni Luh Putu. 2020. Pengelolaan Sampah Dari Lingkup Terkecil dan Pemberdayaan Masyarakat sebagai Bentuk Tindakan Peduli Lingkungan. Jurnal Bali Membangun Bali, Volume 1, Nomor 1, April 2020. Dikutip dari" http://ejournal.baliprov.go.id/index.php/jbmb/article/view/106.

Kartika, T., Fajri, K., dan Kharimah, R. 2017. Pengembangan Wisata Heritage Sebagai Daya Tarik Kota Cimahi. Jurnal Manajemen Resort dan Leisure. Vol. 14, No.2, 35- 46.

Nurhidayati, Sri Endah. 2004. Community Based Tourism (CBT) sebagai Pendekatan Pembangunan Pariwisata Berkelanjutan. Jounal Unair, Surabaya, Airlangga University Press.

Nuryanti, Wiendu. 1993. Concept, Perspective and Challenges. Laporan Konferensi Internasional mengenai Pariwisata Budaya. Yogyakarta. Gadjah Mada University Press.

Permana, I Putu Hendika. 2020. Analisis Media Online sebagai Sumber Informasi Wisatawan Australia dalam Mendapatkan Informasi Virus Corona di Bali. Jurnal Bali Membangun Bali, Volume 1, Nomor 2, Agustus 2020. Dikutip dari: http://ejournal.baliprov.go.id/index.php/jbmb/article/view/111.

Tim Editor. 2020. "Covid-19 Belum Berlalu, JBMB Harus Terus Berkembang", Jurnal Bali Membangun Bali, Volume 1, Nomor 2, Agustus 2020. http://ejournal.baliprov.go.id/index.php/jbmb.

Wahyuntari, Ni Luh Putu; I Gusti Putu Sutarma; Dewa Made Suria Antara. 2020. The Implementation of Marketing Mix to Increase Room Sales. Jurnal Bali Membangun Bali, Volume 1, Nomor 1, April 2020. Dikutip dari: http://ejournal.baliprov.go.id/index.php/jbmb/article/view/108 